Check for updates

Cite this: RSC Adv., 2017, 7, 46932

Received 21st August 2017

Accepted 29th September 2017

DOI: $10.1039 / \mathrm{c} 7 \mathrm{ra0} 262 \mathrm{~h}$

rsc.li/rsc-advances

\title{
Configuration and stability of naturally occurring all-cis-tetrahydrofuran lignans from Piper solmsianum $\dagger$
}

\author{
Clécio S. Ramos, ${ }^{a}$ Harrald V. Linnert, ${ }^{\text {b }}$ Marcilio M. de Moraes, ${ }^{b}$ João H. do Amaral, ${ }^{\text {b }}$ \\ Lydia F. Yamaguchib and Massuo J. Kato (D)*b
}

\begin{abstract}
The study of variability of the tetrahydrofuran lignan (-)-grandisin in leaves of Piper solmsianum (Piperaceae) revealed two unknown compounds, that were isolated and determined to be the all-cis tetrahydrofuran

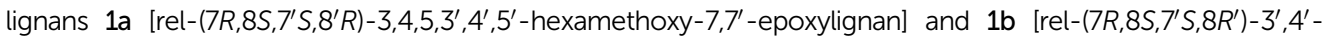
methylenedioxy-3,4,5,5'-tetramethoxy-7,7'-epoxylignan]. Their structures were determined by spectroscopic analysis including 1D and 2D-NMR while their configurations were determined by ECD associated to the density functional theory (DFT) at the B3LYP/6-31G(d,p) level. The hydrogen bonds between methoxy groups in trimethoxyphenyl rings stabilizes the all-trans tetrahydrofuran lignan grandisin by $6.5 \mathrm{kcal} \mathrm{mol}^{-1}$ as compared to the corresponding all-cis isomer of grandisin. The occurrence of all-cis tetrahydrofuran lignans as natural products is a very rare event.
\end{abstract}

\section{Introduction}

Lignans are dimers of phenylpropanoid units widely found in the plant kingdom and with a variety of biological properties such as cytotoxic, antioxidant, antimicrobial, anti-inflammatory, antiviral and immunosuppressive activities. ${ }^{1,2}$ The dimerization process in their formation requires an oxidative coupling mechanism forming a $\beta-\beta$ bonding, which can be followed by further reactions yielding eight different sub-classes including tetrahydrofuran, furofuran, dibenzylbutane, dibenzylbutyrolactone, aryltetralin, arylnaphthalene, dibenzocyclooctadiene and dibenzylbutyrolactol lignans. $^{3-5}$ Tetrahydrofuran (THFs) lignans can be further subdivided in 7,7'-monoepoxy-, 7,9'-monoepoxy- and 9,9'monoepoxy-lignans. The THFs lignans have been described so far from several plant species and their structural diversity results from the type of substituent in the aromatic ring that can be hydroxy, methoxy, methylenedioxy and a combination of them. The relative configuration among aryls and methyl groups can give rise to further stereochemistry diversity. In case of having the same aromatic rings, ten isomers are possible consisting of four diastereomeric pairs besides two meso forms. ${ }^{6}$ The (-)-grandisin is an example of the all-trans tetrahydrofuran lignan, which was formerly isolated from the Lauraceae plants, Litsea grandis ${ }^{7}$ and then from Licaria aurea ${ }^{8}$ and Cryptocarya crassinevia. ${ }^{9}$ Grandisin

\footnotetext{
a Department of Chemistry, Rural Federal University of Pernambuco, Rua Dom Manoel de Medeiros, s/n, 52.171-030 Recife, PE, Brazil

${ }^{b}$ Institute of Chemistry, University of São Paulo, Av. Prof. Lineu Prestes, 748, 05508ooo São Paulo, SP, Brazil. E-mail: majokato@iq.ups.br

$\dagger$ Electronic supplementary information (ESI) available: NMR spectra of 1a and 1b; Fig. S1-S11, Tables S1-S7. See DOI: 10.1039/c7ra09262h
}

has also been isolated from monocotiledoneous Araceae,${ }^{10}$ from other Angiosperms families such as Piperaceae, ${ }^{11}$ Myristicaceae, ${ }^{12}$ Magnoliaceae, ${ }^{13}$ Annonaceae ${ }^{14}$ but also from Rosids including Meliaceae, ${ }^{15}$ Violaceae species ${ }^{16}$ and other plant species. The THFs lignans have displayed several biological activities such as antiPAF,${ }^{17}$ antiprotozoal, ${ }^{18-21}$ larvicidal, ${ }^{22,23}$ cytotoxic, ${ }^{24,25}$ estrogenic, ${ }^{25}$ anti-inflammatory, ${ }^{26}$ and NF-KB inhibitory activity. ${ }^{27}$ Thus, some studies have also been addressed to generate analogues. ${ }^{28-31}$ To date, the natural occurrence of all-cis tetrahydrofuran lignan has only been described from Anogeissus acuminata (Combretaceae) ${ }^{32}$ and from Illicium floridanum (Illiciaceae). ${ }^{33}$ Besides, a synthetic version of all-cis had been obtained by catalytic hydrogenation of a furan derivative. ${ }^{34}$ Additionally, a series of synthetic tetrahydrofuran lignans with various stereochemistry were prepared, including the all-cis tetrahydrofuroguaiacin $\mathrm{B}$, in order to evaluate their plant growth inhibitory activity. ${ }^{31}$ Herein we report on the isolation and structural determination of two novel all-cis tetrahydrofuran lignans $\mathbf{1 a}$ and $\mathbf{1 b}$ from the leaves of two specimens of Piper solmsianum. Besides, two known lignans $\mathbf{2} \mathbf{b}$ and $\mathbf{3 a}$ were also isolated (Fig. 1). The structures of the last two tetrahydrofuran lignans had been only reported without the assignment of their configurations or optical rotations. ${ }^{10,15,35}$ The determination of configuration of THFs lignans (1a, $\mathbf{1} \mathbf{b}, \mathbf{2} \mathbf{b}$ and $\mathbf{3 a}$ ) were carried out using electronic circular dichroism (ECD) having (-)-grandisin as reference data since its configuration was previously reported based on crystallographic studies. ${ }^{14}$ Additionally, since natural allcis tetrahydrofuran lignans, such as $\mathbf{1 a}$ and $\mathbf{1 b}$, are of rare occurrence a study of structural stability were undertaken using density functional theory (DFT) at the B3LYP/6-31G(d,p) level. The relative energies of lignans 1a and 3a were compared to that of all-trans lignan (-)-grandisin (2a). Solvent effects were analysed by the self- 


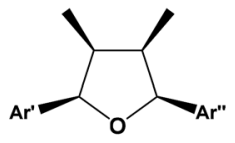

1a $\mathrm{Ar}^{\prime}=\mathrm{Ar}^{\prime \prime}=\mathrm{Ar}_{2}$ 1b $A r^{\prime}=A r_{2} ; A r^{\prime \prime}=A r_{3}$

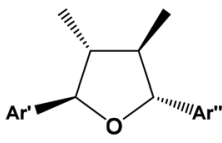

2a $A r^{\prime}=A r^{\prime \prime}=A r_{2}$

2b $\mathrm{Ar}^{\prime}=\mathrm{Ar}^{\prime \prime}=\mathrm{Ar}_{3}$

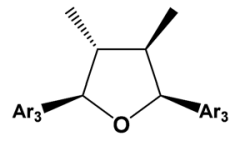

3a
$\mathrm{Ar}_{2}=3,4,5$-trimethoxyphenyl

$\mathrm{Ar}_{3}=3$,4-methylenedioxy-5-methoxyphenyl

Fig. 1 Tetrahydrofuran lignans from $P$. solmsianum.

consistence reaction field (SCRF) method, and the energy difference in water and cyclohexane environments were determined with the polarizable continuum model PCM(B3LYP/6-31G(d,p)) method.

\section{Results and discussions}

\section{Analysis of crude extracts from $P$. solmsianum}

The tetrahydrofuran lignan (-)-grandisin has displayed several bioactivities and thus, the initial approach was to determine its variability in specimens of $P$. solmsianum occurring in several sites in São Paulo State. The initial survey in samples from leaves of different sites revealed common profiles based on the occurrence of phenylpropanoids apiole-dillapiole and grandisin (2a). Then, the analysis of chemical variability of a population of $P$. solmsianum occurring in the Campus of University of São Paulo was undertaken and several samples collected presented an unusual chromatographic profile with one major peak with shorter retention time than that of grandisin. These extracts were submitted to ${ }^{1} \mathrm{H}$ NMR analysis, which suggested the occurrence of a major tetrahydrofuran lignan (1a) with similar oxygenation pattern in the aromatic rings with six methoxy groups. Crude extracts from different $P$. solmsianum individuals collected in Alberto Löfgren State Park analysed by HPLC indicated a second tetrahydrofuran lignan, having methoxy and 3,4-methylenedioxy groups (1b). Thus, both compounds were isolated and had their structures determined by spectroscopic analysis.

\section{Structural determination of lignans $1 \mathrm{a}, 1 \mathrm{~b}, 2 \mathrm{~b}$ and $3 \mathrm{a}$}

The lignan 1a was isolated as a pale white powder with purity of 99.6\% by HPLC. Its HR-ESIMS spectrum displayed a quasimolecular ion $[\mathrm{M}+\mathrm{H}]^{+}$peak at $m / z 433.2232$ corresponding to

Table 1 NMR spectral data ${ }^{a}$ for lignans $1 \mathrm{a}$ and $1 \mathrm{~b}$

\begin{tabular}{|c|c|c|c|c|c|c|c|c|}
\hline \multirow[b]{2}{*}{ Position } & \multicolumn{4}{|l|}{$1 \mathbf{a}$} & \multicolumn{4}{|l|}{$1 \mathbf{b}$} \\
\hline & $\delta^{1} \mathrm{H}$ & COSY & $\delta{ }^{13} \mathrm{C}$ & HMBC & $\delta^{1} \mathrm{H}$ & COSY & $\delta{ }^{13} \mathrm{C}$ & HMBC \\
\hline 1 & - & - & 137.0 & $\mathrm{C} 6, \mathrm{C} 2$ & - & - & 135.3 & $\mathrm{C} 6, \mathrm{C} 2$ \\
\hline 2 & $6.67(\mathrm{~s}, 1 \mathrm{H})$ & $\mathrm{H} 7$ & 103.6 & $\mathrm{C} 6, \mathrm{C} 7, \mathrm{C} 8, \mathrm{C} 4, \mathrm{C} 3$ & $6.65(\mathrm{~s}, 1 \mathrm{H})$ & $\mathrm{H} 7$ & 103.5 & $\mathrm{C} 6, \mathrm{C} 7$ \\
\hline 3 & - & - & 153.1 & $\mathrm{C} 2, \mathrm{OCH}_{3}-3$ & - & - & 153.0 & $\mathrm{C} 2, \mathrm{OCH}_{3}-3$ \\
\hline 4 & - & - & 136.0 & $\mathrm{C}-6, \mathrm{OCH}_{3}-4$ & - & - & 137.5 & $\mathrm{C} 6, \mathrm{OCH}_{3}-4$ \\
\hline 5 & - & - & 153.1 & $\mathrm{C}-6, \mathrm{OCH}_{3}-5$ & - & - & 153.0 & $\mathrm{C} 6, \mathrm{OCH}_{3}-5$ \\
\hline 6 & $6.67(\mathrm{~s}, 1 \mathrm{H})$ & $\mathrm{H} 7$ & 103.6 & $\mathrm{C} 2, \mathrm{C} 7, \mathrm{C} 8, \mathrm{C} 4, \mathrm{C} 5$ & $6.65(\mathrm{~s}, 1 \mathrm{H})$ & $\mathrm{H} 7$ & 103.5 & $\mathrm{C} 2, \mathrm{C} 7$ \\
\hline 7 & $\begin{array}{l}5.11 \\
(\mathrm{~d}, J 6.7 \mathrm{~Hz}, 1 \mathrm{H})\end{array}$ & $\begin{array}{l}\mathrm{H} 8, \mathrm{H} 9 \\
\mathrm{H} 2, \mathrm{H} 6\end{array}$ & 82.9 & $\mathrm{C} 9, \mathrm{C} 8^{\prime}, \mathrm{C} 2, \mathrm{C} 3, \mathrm{C} 1$ & $\begin{array}{l}5.09 \\
(\mathrm{~d}, J 7.0 \mathrm{~Hz}, 1 \mathrm{H})\end{array}$ & $\begin{array}{l}\text { H8, } \\
\text { H9 H2, H6 }\end{array}$ & 82.8 & $\mathrm{C} 9, \mathrm{C} 2, \mathrm{C} 3$ \\
\hline 8 & $2.70(\mathrm{~m}, 1 \mathrm{H})$ & H7, H9 & 41.6 & $\begin{array}{l}\mathrm{C} 7, \mathrm{C}^{\prime}, \\
\mathrm{C} 8^{\prime}, \mathrm{C} 9, \mathrm{C} 9^{\prime}, \mathrm{C} 1\end{array}$ & $2.67(\mathrm{~m}, 1 \mathrm{H})$ & $\mathrm{H} 7, \mathrm{H} 9$ & 41.5 & $\begin{array}{l}\mathrm{C} 7, \mathrm{C}^{\prime}, \\
\mathrm{C} 8^{\prime}, \mathrm{C} 9, \mathrm{C} 9^{\prime}\end{array}$ \\
\hline 9 & $\begin{array}{l}0.64 \\
(\mathrm{~d}, J 6.7 \mathrm{~Hz}, 3 \mathrm{H})\end{array}$ & $\mathrm{H} 8, \mathrm{H7}$ & 11.6 & $\mathrm{C}^{\prime}, \mathrm{C} 8, \mathrm{C} 8{ }^{\prime}, \mathrm{C} 7, \mathrm{C} 1$ & $\begin{array}{l}0.64 \\
(\mathrm{~d}, J 6.9 \mathrm{~Hz}, 3 \mathrm{H})\end{array}$ & $\mathrm{H} 8, \mathrm{H} 7$ & 11.6 & $\mathrm{C} 8, \mathrm{C} 8^{\prime}, \mathrm{C} 7$ \\
\hline $1^{\prime}$ & - & - & 137.0 & $\mathrm{C} 6^{\prime}, \mathrm{C} 2^{\prime}$ & - & - & 136.1 & $\mathrm{C} 6^{\prime}, \mathrm{C} 2^{\prime}$ \\
\hline $2^{\prime}$ & $6.67(\mathrm{~s}, 1 \mathrm{H})$ & $\mathrm{H} 7^{\prime}$ & 103.6 & $\begin{array}{l}\mathrm{C} 6^{\prime}, \mathrm{C} 7^{\prime}, \\
\mathrm{C} 8^{\prime}, \mathrm{C} 4^{\prime}, \mathrm{C} 3^{\prime}\end{array}$ & $6.63(\mathrm{~s}, 1 \mathrm{H})$ & $\mathrm{H}^{\prime}$ & 105.8 & $\mathrm{C} 6^{\prime}, \mathrm{C} 7^{\prime}$ \\
\hline $3^{\prime}$ & - & - & 153.1 & $\mathrm{O}_{2} \mathrm{CH}_{2}, \mathrm{C} 2^{\prime}$ & - & - & 143.4 & $\mathrm{O}_{2} \mathrm{CH}_{2}, \mathrm{C} 2^{\prime}$ \\
\hline $4^{\prime}$ & - & - & 136.0 & $\mathrm{O}_{2} \mathrm{CH}_{2}, \mathrm{C}^{\prime}$ & - & - & 139.8 & $\mathrm{O}_{2} \mathrm{CH}_{2}, \mathrm{C}^{\prime}$ \\
\hline $5^{\prime}$ & - & - & 153.1 & $\mathrm{C}^{\prime}, \mathrm{OCH}_{3}-5^{\prime}$ & - & - & 148.8 & $\mathrm{C}^{\prime}, \mathrm{OCH}_{3}-5^{\prime}$ \\
\hline $6^{\prime}$ & $6.67(\mathrm{~s}, 1 \mathrm{H})$ & $\mathrm{H} 7^{\prime}$ & 103.6 & $\mathrm{C} 2^{\prime}, \mathrm{C}^{\prime}, \mathrm{C} 8^{\prime}, \mathrm{C} 4^{\prime}, \mathrm{C} 5^{\prime}$ & $6.61(\mathrm{~s}, 1 \mathrm{H})$ & $\mathrm{H} 7^{\prime}$ & 100.7 & $\mathrm{C} 2^{\prime}, \mathrm{C}^{\prime}$ \\
\hline $7^{\prime}$ & $\begin{array}{l}5.11 \\
(\mathrm{~d}, J 6.7 \mathrm{~Hz}, 1 \mathrm{H})\end{array}$ & $\begin{array}{l}\mathrm{H}^{\prime}, \mathrm{H}^{\prime}, \\
\mathrm{H} 2^{\prime}, \mathrm{H}^{\prime}\end{array}$ & 82.9 & $\mathrm{C} 9^{\prime}, \mathrm{C} 8, \mathrm{C} 2^{\prime}, \mathrm{C} 3^{\prime}, \mathrm{C} 1^{\prime}$ & $\begin{array}{l}5.09 \\
(\mathrm{~d}, J 7.0 \mathrm{~Hz}, 1 \mathrm{H})\end{array}$ & $\begin{array}{l}\mathrm{H} 8^{\prime}, \\
\mathrm{H} 9^{\prime}, \mathrm{H} 2^{\prime}, \mathrm{H} 6^{\prime}\end{array}$ & 82.9 & $\mathrm{C} 9^{\prime}, \mathrm{C} 2^{\prime}, \mathrm{C} 3^{\prime}$ \\
\hline $8^{\prime}$ & $2.70(\mathrm{~m}, 1 \mathrm{H})$ & $\mathrm{H}^{\prime}, \mathrm{H}^{\prime}$ & 41.6 & $\mathrm{C} 7, \mathrm{C}^{\prime}, \mathrm{C} 8, \mathrm{C} 9, \mathrm{C} 9^{\prime}, \mathrm{C} 1^{\prime}$ & $2.67(\mathrm{~m}, 1 \mathrm{H})$ & $\mathrm{H}^{\prime}, \mathrm{H}^{\prime}$ & 41.6 & $\begin{array}{l}\mathrm{C} 7, \mathrm{C}^{\prime} \\
\mathrm{C} 8, \mathrm{C} 9, \mathrm{C} 9^{\prime}\end{array}$ \\
\hline $9^{\prime}$ & $\begin{array}{l}0.64 \\
(\mathrm{~d}, J 6.7 \mathrm{~Hz}, 3 \mathrm{H})\end{array}$ & $\mathrm{H} 8^{\prime}, \mathrm{H}^{\prime}$ & 11.6 & $\mathrm{C} 9, \mathrm{C} 8, \mathrm{C} 8^{\prime}, \mathrm{C}^{\prime}, \mathrm{C} 1^{\prime}$ & $\begin{array}{l}0.62 \\
(\mathrm{~d}, J 6.9 \mathrm{~Hz}, 3 \mathrm{H})\end{array}$ & $\mathrm{H} 8^{\prime}, \mathrm{H}^{\prime}$ & 11.7 & $\mathrm{C} 8, \mathrm{C}^{\prime}, \mathrm{C}^{\prime}$ \\
\hline $\mathrm{OCH}_{3} / 3$ & $3.88(\mathrm{~s}, 3 \mathrm{H})$ & - & 56.1 & $\mathrm{C} 3$ & $3.88(\mathrm{~s}, 3 \mathrm{H})$ & & 56.1 & - \\
\hline $\mathrm{OCH}_{3} / 3^{\prime}$ & $3.88(\mathrm{~s}, 3 \mathrm{H})$ & - & 56.1 & $\mathrm{C} 3^{\prime}$ & - & & - & - \\
\hline $\mathrm{OCH}_{3} / 4$ & $3.86(\mathrm{~s}, 3 \mathrm{H})$ & - & 60.9 & $\mathrm{C} 4$ & $3.86(\mathrm{~s}, 3 \mathrm{H})$ & & 60.9 & - \\
\hline $\mathrm{OCH}_{3} / 4^{\prime}$ & $3.86(\mathrm{~s}, 3 \mathrm{H})$ & - & 60.9 & $\mathrm{C} 4^{\prime}$ & - & & - & - \\
\hline $\mathrm{OCH}_{3} / 5$ & $3.88(\mathrm{~s}, 3 \mathrm{H})$ & - & 56.1 & C5 & $3.88(\mathrm{~s}, 3 \mathrm{H})$ & & 56.1 & - \\
\hline $\mathrm{OCH}_{3} / 5^{\prime}$ & $3.88(\mathrm{~s}, 3 \mathrm{H})$ & - & 56.1 & $\mathrm{C}^{\prime}$ & $3.91(\mathrm{~s}, 3 \mathrm{H})$ & & 56.6 & - \\
\hline $\mathrm{O}_{2} \mathrm{CH}_{2}$ & & & & & $5.98(\mathrm{~s}, 2 \mathrm{H})$ & & 101.3 & - \\
\hline
\end{tabular}

${ }^{a} 500 \mathrm{MHz}$ for ${ }^{1} \mathrm{H}$ and $125 \mathrm{MHz}$ for ${ }^{13} \mathrm{C}$; compounds dissolved in $\mathrm{CDCl}_{3}$; $\delta$ in ppm relative to TMS, $J$ in $\mathrm{Hz}$. 
the molecular formula $\mathrm{C}_{24} \mathrm{H}_{33} \mathrm{O}_{7}$. The IR of $1 \mathrm{a}$ showed no absorptions near $3400 \mathrm{~cm}^{-1}$, but an intense band at $1128 \mathrm{~cm}^{-1}$ suggesting C-O-C functions. The simplicity of the ${ }^{1} \mathrm{H}$ and ${ }^{13} \mathrm{C}$ NMR spectra (Fig. S1 and S2; ESI $\dagger$ ) indicated that $1 \mathrm{a}$ is a symmetrical compound (Table 1). The dimethyl-tetrahydrofuran moiety could be readily recognized in the ${ }^{1} \mathrm{H}$ NMR spectrum by the doublets at $\delta_{\mathrm{H}} 0.64\left(6 \mathrm{H}, J=6.7 \mathrm{~Hz}, \mathrm{H}-9 / \mathrm{H}^{\prime} 9^{\prime}\right)$ and $5.11(2 \mathrm{H}$, $\left.J=6.7 \mathrm{~Hz}, \mathrm{H}-7 / \mathrm{H}-7^{\prime}\right)$, and a multiplet at $\delta_{\mathrm{H}} 2.70\left(2 \mathrm{H}, \mathrm{H}-8 / \mathrm{H}-8^{\prime}\right)$. The singlet at $\delta_{\mathrm{H}} 6.74\left(\mathrm{H}-2 / \mathrm{H}-2^{\prime}, \mathrm{H}-6 / \mathrm{H}-6^{\prime}\right)$ was assigned to the two equivalent ortho-methoxy aromatic hydrogens, while the intense singlets at $\delta_{\mathrm{H}} 3.88\left(4 \times \mathrm{OCH}_{3} ; 3,3^{\prime}, 5,5^{\prime}\right)$ and $3.86\left(2 \times \mathrm{OCH}_{3} ; 4,4^{\prime}\right)$ corresponded to the six methoxy groups. The structure of $\mathbf{1 a}$ bearing two 3,4,5-trimethoxyphenyl groups was firmly supported by further ${ }^{13} \mathrm{C}$ NMR analysis (Table 1). ${ }^{3,35,36}$ All NMR assignments were confirmed by HSQC and HMBC correlations in which cross peaks were observed between the aromatic and aliphatic nuclei (Fig. S3 and $\mathrm{S} 4 \dagger$ ).

Considering the symmetry observed in the ${ }^{1} \mathrm{H}$ and ${ }^{13} \mathrm{C}$ NMR spectra and that $\mathbf{1 a}$ is optically inactive, the compound was determined as a meso isomer with configuration similar to the all-cis (1c) or trans-cis-trans (5) (Table S1†). The determination of the relationship between the methyl and the aryl groups was based on the chemical shifts of methyl $\left(\mathrm{H}-9 / \mathrm{H}-\mathrm{9}^{\prime}\right)$ and oxymethine $\left(\mathrm{H}-7 / \mathrm{H}-\mathrm{7}^{\prime}\right)$ protons, and of the oxybenzylic carbons $\left(\mathrm{C}-7 / \mathrm{C}-\mathrm{7}^{\prime}\right)$ (Tables 1 and $\mathrm{S} 1 \dagger$ )., ${ }^{3,8,32}$ The protons at $\mathrm{H}-9 / \mathrm{H}-9^{\prime}$ and $\mathrm{H}-7 / \mathrm{H}-\mathbf{7}^{\prime}$ of $\mathbf{1 a}$ showed signals at $\delta_{\mathrm{H}} 0.64$ and 5.11, respectively and the coupling constants of $J 6.7 \mathrm{~Hz}$ for the $\mathrm{H}-7 / \mathrm{H}-8\left(\mathrm{H}-7^{\prime} / \mathrm{H}-8^{\prime}\right)$ hydrogens is compatible with a dihedral angle of approximately $30^{\circ}$, indicating all-cis relationship between the methyl and aryl substituents. ${ }^{32}$ The up-field shifted methyl carbons at $\delta_{\mathrm{C}} 11.6$ in the ${ }^{13} \mathrm{C} \mathrm{NMR}$ is contrasting to the all-trans isomer grandisin (2a), which appeared at $\delta_{\mathrm{C}}$ 13.9. This shielding effect has been assigned to the anisotropic effect of the pseudo-axially oriented aromatic ring on the methyl groups of 1a. The chemical shifts of C-7/C-7' observed at $\delta_{\mathrm{C}}$ 82.9, and of $\mathrm{C}-8 / \mathrm{C}-8^{\prime}$ at $\delta_{\mathrm{C}} 41.6$, provided further evidences for the cis configurations between the methyl and aryl groups of 1a (Tables 1 and $\mathrm{S} 1 \dagger$ ). All the ${ }^{1} \mathrm{H}$ and ${ }^{13} \mathrm{C}$ NMR data indicated that the lignan 1a is all-cis isomer of $\mathbf{2 a}$ (grandisin) ${ }^{35}$ thus, the structure was determined as rel-( $\left.7 R, 8 S, 7^{\prime} S, 8^{\prime} R\right)-3,4,5,3^{\prime}, 4^{\prime}, 5^{\prime}$-hexamethoxy-7, $7^{\prime}$ epoxylignan.

Compound 1b was isolated as pale-yellow oil by preparative TLC of a methanolic extract of the leaves of $P$. solmsianum with 99.2\% purity indicated by HPLC analysis. The molecular formula of $\mathbf{1 b}$ was determined as $\mathrm{C}_{23} \mathrm{H}_{28} \mathrm{O}_{7}$ according to the quasimolecular ion $[\mathrm{M}+\mathrm{H}]^{+}$observed in the HR-ESIMS at $m / z$ 417.1915.

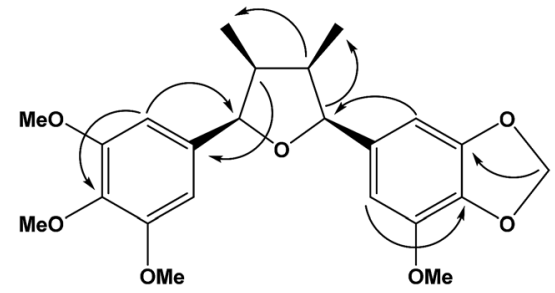

Fig. 2 Important ${ }^{1} \mathrm{H}-{ }^{13} \mathrm{C}$ observed in the $\mathrm{HMBC}$ correlations of lignan $1 b$.
Analysis of the ${ }^{1} \mathrm{H}$ and ${ }^{13} \mathrm{C}$ NMR spectra of $\mathbf{1 b}$ indicated the structure of an all-cis tetrahydrofuran lignan similarly to 1a (Table 1; Fig. S5 and S6†). The major differences were associated to the replacement of two methoxy by one methylenedioxy group, which account for the difference of 16 Da between the molecular ions of $\mathbf{1 a}$ and $\mathbf{1 b}$. The chemical shift of the equivalent aromatic hydrogens of the 3,4,5-trimethoxyphenyl ring $\left(\delta_{\mathrm{H}} 6.65, \mathrm{~s}, 2 \mathrm{H}\right)$ was similar to that of 1a, while the hydrogens of the second aromatic ring appeared as two broad singlets at $\delta_{\mathrm{H}} 6.63$ and 6.61 and were assigned to the two aromatic hydrogens of the 3-methoxy-4,5methylenedioxyphenyl ring. The HMBC contour plot (Fig. S8 $\dagger$ ) displayed correlations between the oxymethine protons $\left(\mathrm{H}-7 / \mathrm{H}-\mathrm{7}^{\prime}\right)$ to $\mathrm{C}-6 / \mathrm{C}-6^{\prime}$ and $\mathrm{C}-2 / \mathrm{C}-2^{\prime}$, and between the $\mathrm{H}-7 / \mathrm{H}-\mathrm{7}^{\prime}$ hydrogens to signals of $\mathrm{C}-9 / \mathrm{C}-9^{\prime}$ (Fig. 2). All NMR data, including HSQC (Fig. S7 $\dagger$ ), confirmed the assignments made and thus $\mathbf{1 b}$ was determined as rel-( $\left.7 R, 8 S, 7^{\prime} S, 8^{\prime} R\right)-3^{\prime}, 4^{\prime}$-methylenedioxy-3,4,5, $5^{\prime}$-tetramethoxy-7,7'-epoxylignan.

Compound $\mathbf{2 b}$ has been reported previously as rel$\left(7 R, 8 S, 7^{\prime} S, 8^{\prime}\right)-3^{\prime}, 4^{\prime}$-methylenedioxy-3,4,5, $5^{\prime}$-tetramethoxy-7,7'epoxylignan. ${ }^{35}$

The compound 3a, determined as (-)-epigrandisin based on the spectrometric data analysis, is a lignan formerly isolated from the stem bark of Aglaia leptantha but characterized in a mixture with (-)-grandisin (2a) with an estimated $[\alpha]_{\mathrm{D}}^{21}$ value of $-15 \pm$ $10 .^{15}$ (-)-Epigrandisin, without configuration assigned, was also reported from leaves of Rhaphidophora decursiva. ${ }^{\mathbf{1 0}}$

\section{Determination of relative configurations of lignans $1 a, 1 b, 2 b$ and 3a}

The relative configurations of the THF lignans $\mathbf{1 a}, \mathbf{1 b}, \mathbf{2} \mathbf{b}$ and $\mathbf{3 a}$ were determined by comparison of ECD spectra with that of (-)-grandisin (2a) (Fig. 3), in which its configuration had been previously determined by X-ray analysis. ${ }^{7}$ Lignan $1 \mathrm{a}$ is optically inactive and no Cotton effect was observed in its ECD curve. The ECD curve of lignan $\mathbf{2 b}$ was very similar to that of $(-)$-grandisin (2a) with a negative Cotton effect at $233 \mathrm{~nm}$, indicating the trans configuration between the aromatic rings. In contrast, the lignans $\mathbf{1 b}$ and 3a showed a positive Cotton effect at $220 \mathrm{~nm}$ in the ECD curve, i.e. opposite to that of $\mathbf{2 a}$, hence the cis configuration between the aromatic rings were assigned (Fig. 3).

\section{Energetics of the lignans in gas phase}

Optimization of the tetrahydrofuran lignans (gas phase) structures was performed with the aid of Gaussian 03 (revision B.05) software,$^{37}$ using DFT at the B3LYP level with the 6-31G(d,p) basis set. Becke's three parameter adiabatic connection approach is well established to provide structural parameters for large molecules including the intramolecular and intermolecular hydrogen bondings. ${ }^{38,39}$ Harmonic frequencies were calculated in order to confirm the equilibrium geometries corresponding to minima energy and zero point energy (ZPE). Correction term was added to the electronic energies of the calculated structures to estimate differences in the relative energies between the lignans 1a, 2a and 3a (Table S2 $\dagger$ ).

In order to predict the energy and the solvent effect on lignans stability in polar and apolar environments, an single 


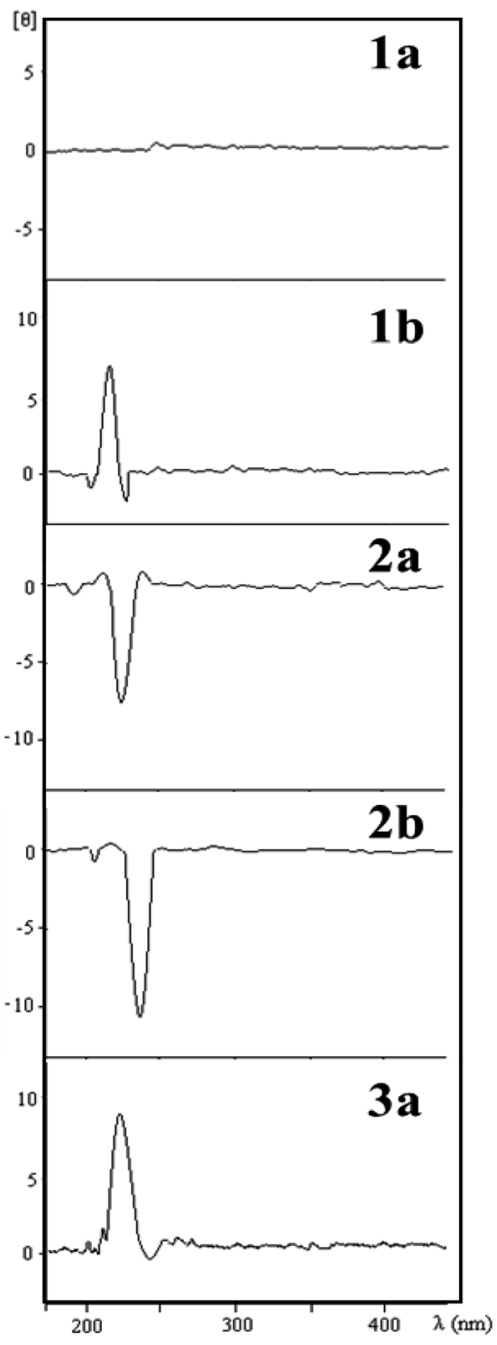

Fig. 3 ECD curves of tetrahydrofuran lignans from $P$. solmsianum.

point energy calculation was performed, with the PCM (B3LYP) SCRF models using the $6-31 \mathrm{G}(\mathrm{d}, \mathrm{p})$ basis set. The tight SCF convergence criteria were specified for all jobs and the predicted energy and solvent effects in cyclohexane and water media were calculated (ESI, Table S3†).

The calculations at the B3LYP/6-31G(d,p) level indicated lignan $\mathbf{2 a}$ as the most stable among the lignans $\mathbf{1 a}$ and $\mathbf{3 a}$ in gas phase, cyclohexane and water. An exception was observed for lignans 2a and 3a, which have similar electronic energy in water medium (Tables S2 and S3†). The calculations showed that inclusion of solvent effects does not change the overall relative results obtained in the gas phase. Furthermore, the stabilities increased with the solvent polarity, and only the change in the energy produced in the high polar medium (i.e., water) was more effective in stabilizing the conformers as compared to the gas phase or apolar solvent (i.e., cyclohexane).

\section{Gas phase optimization geometry of the THF lignans}

A remarkable feature in the analysis of the geometrical parameters of $\mathbf{1 a}, \mathbf{1 b}, \mathbf{2 a}, \mathbf{2} \mathbf{b}$ and $\mathbf{3 a}$ lignans is the stabilization resulting from intramolecular $\mathrm{C}-\mathrm{H} \cdots \mathrm{O}$ hydrogen bonding.
Energy calculations predict that the all-trans THF lignan 2a would be $0.42 \mathrm{kcal} \mathrm{mol}^{-1}$ more stable than epigrandisin $3 \mathrm{a}$, and $6.5 \mathrm{kcal} \mathrm{mol}^{-1}$ more stable than the all-cis THF lignan 1a. Such sequence of stability is somewhat compatible with the rare natural occurrence of all-cis THF lignan isomer. In fact, there are only two previous report for it. ${ }^{32,33}$ It is also noteworthy that the methyl group ( $\left.\mathrm{Cg}^{\prime}\right)$ attached to the THF ring lies close to the aromatic rings in the all-cis lignan 1a, revealing one further possible hydrogen bonding contributing to an unfavourable gauche conformation around the $\mathrm{C}^{\prime}$ bond (Fig. S9†). Accordingly, the calculated angle at $\mathrm{C} 8-\mathrm{C}^{\prime}-\mathrm{C}^{\prime}$ is $3^{\circ}$ smaller than the corresponding $\mathrm{C} 7-\mathrm{C} 8-\mathrm{C} 8^{\prime}$ angle at the THF ring, a feature also observed in 1b. Additionally, the phenyl rings in 1a lie closer to the THF ring compared with the all-trans isomer, resulting in smaller dihedral angles, which is less favourable.

The results concerning structural changes associated to the phenyl rings suggested that the geometrical equilibrium structures of $\mathbf{1 b}$ and $\mathbf{2 b}$ are dependent on intramolecular hydrogen bonding. On the other hand, the geometrical energy minimization of $\mathbf{2 b}$ taking into account both hydrogens but not hydrogen bonding (a difference of $\sim 1 \mathrm{kcal} \mathrm{mol}^{-1}$ ), showed that these additional hydrogen bonds are not energetically significant. It is also worth to note that in these geometry optimizations, the methoxy groups attached to each of the phenyl ring do not necessary lie close to the ring plane, but assumed the most favourable hydrogen bonding with conformers differing from those of crystallographic data. ${ }^{14}$

The calculated equilibrium geometries for lignans 1a-2a are shown in Fig. S9 and S10 (ESI $\dagger$ ), and the main geometrical parameters, obtained after minimized energies using the B3LYP method, are presented in Tables S4-S7 (ESI $\dagger$ ).

\section{Relative energies of the THF isomers without methoxy groups in the phenyl rings}

In order to compare the behavior of the THF lignan isomers, a singular qualitative calculation was made for the ten possible tetrahydrofuran isomers (four diastereomeric pairs and two meso forms) (Table S8†) with a lower level of theory as B3LYP/3$21 \mathrm{G}^{*}$. The methoxy groups were not included in the calculation in order to minimize the effect of the hydrogen bondings in the stabilities and thus to determine only the effect of configuration in the stabilities of THF rings. The electronic energy of the optimized structures indicates that the all trans and the all cis structures are the most and the least stable among the ten stereoisomers, respectively (Table S8†). With this finding, we can predict that the configuration and the degree of methoxylation contribute to the stabilization of the THFs lignans.

\section{Conclusions}

The structures and absolute configurations of two novel THF lignans $(\mathbf{1 a}, \mathbf{1 b})$, isolated from leaves of the species $P$. solmsianum, and of two known lignans $(\mathbf{2} \mathbf{b}, 3 \mathbf{3 a}),{ }^{10,15,35}$ were determined. In addition, the theoretical electronic calculations provided a new data set for the structures of the THF lignans in gas phase showing that the configuration of the tetrahydrofuran 
ring and intramolecular hydrogen bonding are related to the geometrical equilibrium energy profile of the conformers. The calculated energies in the gas phase and in solvents (water and cyclohexane) indicated that lignan $2 \mathbf{a}$ is the most stable among the isomeric lignans 1a-3a. Moreover, the calculated data for $\mathbf{1 b}$ and $\mathbf{2 b}$ could explain the theoretical equilibrium geometries of these lignans since the configuration of the THF ring and intramolecular hydrogen bonding originated from the methoxy groups in the phenyl ring, compared to the methylenedioxy moiety, contributed to the stabilization of the THF lignan structures.

\section{Experimental}

\section{Plant material}

Leaves of Piper solmsianum C. DC were collected at the Instituto de Biociências (IB), Universidade de São Paulo (SP, Brazil) and at the Horto Florestal (HF), Instituto Florestal do Estado de Sao Paulo (SP, Brazil) in January 2003 (Permit ICMBio-15780-1). Plants were identified by Dr Elsie Franklin Guimarães (Instituto de Pesquisas Jardim Botânico do Rio de Janeiro, RJ, Brazil), and voucher specimens were deposited at the herbarium of the Instituto de Pesquisas Jardim Botânico do Rio de Janeiro (IB specimen - Kato-0367; HF specimen - Kato-0175).

\section{Extraction and isolation of lignan 1a}

Dried leaves ( $3.2 \mathrm{~g}$ ) of $P$. solmsianum (IB specimens) were milled and the powder extracted with $\mathrm{CH}_{2} \mathrm{Cl}_{2}$ for $48 \mathrm{~h}$. The extract was concentrated under vacuum to yield $300 \mathrm{mg}$ of a residue that was submitted to CC over C18 column (7 g, $15 \times 2.5 \mathrm{~cm}$ i.d.). Elution with mixtures of $\mathrm{H}_{2} \mathrm{O}: \mathrm{MeOH}$ containing increasing amounts of $\mathrm{MeOH}$ (from 50 to $100 \%$ ) gave 10 fractions. Fractions 3 and 4 (eluted with $70 \% \mathrm{MeOH}$ ) were pooled, extracted with $\mathrm{CH}_{2} \mathrm{Cl}_{2}(3 \times 100 \mathrm{~mL})$, the organic fractions dried over anhydrous $\mathrm{Na}_{2} \mathrm{SO}_{4}$ and concentrated under vacuum to yield 1a (6 mg). Data for compound 1a: pale white powder; $[\alpha]_{\mathrm{D}}^{21} 0(c 1 \times$ $\left.10^{-4} \mathrm{~mol} \mathrm{~L}^{-1}, \mathrm{CH}_{2} \mathrm{Cl}_{2}\right)$; UV $\lambda_{\max } 225 \mathrm{~nm}\left(c 3.0 \times 10^{-2} \mathrm{~mol} \mathrm{~L}^{-1}\right.$ $\mathrm{MeOH}) ; \mathrm{CD} \theta_{220 \mathrm{~nm}}+6.6\left(c 2.5 \times 10^{-3} \mathrm{~mol} \mathrm{~L}^{-1} \mathrm{MeOH}\right) ; \mathrm{IR}$ $\nu_{\max }^{\text {film }} \mathrm{cm}^{-1}: 2965,2930,2837,1593,1127,1095,843 ;{ }^{1} \mathrm{H}$ and ${ }^{13} \mathrm{C}$ NMR: see Table 1; EI/MS m/z (rel. int): $432[\mathrm{M}]^{+}$(31), 236 (100), 221 (70), 205 (83); HR-ESIMS [M $+\mathrm{H}]^{+}$calcd for $\mathrm{C}_{24} \mathrm{H}_{33} \mathrm{O}_{7}$ 433.2221, found 433.2232. Anal. calcd for $\mathrm{C}_{24} \mathrm{H}_{32} \mathrm{O}_{7}: \mathrm{C}, 66.66 ; \mathrm{H}$, 7.40; O, 25.92. Found C, 66.57; H, 7.25; O 25.88.

\section{Extraction and isolation of lignans $1 \mathrm{~b}, 2 \mathrm{~b}$ and $3 \mathrm{a}$}

Dried leaves ( $6 \mathrm{~g}$ ) of $P$. solmsianum (HF specimens) were milled and the powder extracted with methanol for $48 \mathrm{~h}$. The extract was concentrated under vacuum to yield $400 \mathrm{mg}$ of a residue that was suspended in $150 \mathrm{~mL}$ of $\mathrm{MeOH}: \mathrm{H}_{2} \mathrm{O}(4: 1)$, filtered over a bed of Celite, and extracted with $\mathrm{CH}_{2} \mathrm{Cl}_{2}(3 \times 100 \mathrm{~mL})$. The $\mathrm{CH}_{2} \mathrm{Cl}_{2}$ fraction was dried over anhydrous $\mathrm{Na}_{2} \mathrm{SO}_{4}$, concentrated under vacuum to yield $70 \mathrm{mg}$ of residue that was submitted to preparative TLC developed twice with hexanes : EtOAc (85: 15) to afford $\mathbf{1 b}(10 \mathrm{mg}), \mathbf{2 b}(3 \mathrm{mg})$ and $\mathbf{3 a}$ (5 mg). Data for compound 1b: pale yellow oil; $[\alpha]_{\mathrm{D}}^{21}+80.7$ (c 1 $1 \times$ $\left.10^{-4} \mathrm{~mol} \mathrm{~L}^{-1}, \mathrm{CH}_{2} \mathrm{Cl}_{2}\right)$; UV $\lambda_{\max } 225 \mathrm{~nm}\left(c 3.0 \times 10^{-2} \mathrm{~mol} \mathrm{~L}^{-1}\right.$
$\mathrm{MeOH}) ; \mathrm{CD} \theta_{220 \mathrm{~nm}}+6.6\left(c 2.5 \times 10^{-3} \mathrm{~mol} \mathrm{~L}{ }^{-1} \mathrm{MeOH}\right) ; \mathrm{IR}$ $\nu_{\max }^{\text {film }} \mathrm{cm}^{-1}: 2965,2935,1634,1507,1233,1228,1095,843 ;{ }^{1} \mathrm{H}$ and ${ }^{13} \mathrm{C}$ NMR: see Table 1; EI/MS $m / z$ (rel. int): $416[\mathrm{M}]^{+}$(14), 220 (100), 205 (85), 236 (43), 208 (21); HR-ESIMS [M + H] $]^{+}$calcd for $\mathrm{C}_{23} \mathrm{H}_{28} \mathrm{O}_{7}$ 417.1907, found 417.1915. Data for compound $2 \mathrm{~b}$ : pale white powder; $[\alpha]_{\mathrm{D}}^{21}-62.2\left(c 1 \times 10^{-4} \mathrm{~mol} \mathrm{~L}^{-1}, \mathrm{CH}_{2} \mathrm{Cl}_{2}\right)$; UV $\lambda_{\max } 240 \mathrm{~nm}\left(c 5.0 \times 10^{-2} \mathrm{~mol} \mathrm{~L}^{-1} \mathrm{MeOH}\right) ; \mathrm{CD} \theta_{233 \mathrm{~nm}}-10.5$ $\left(c 3.0 \times 10^{-3} \mathrm{~mol} \mathrm{~L}^{-1} \mathrm{MeOH}\right)$; IR $\nu_{\max }^{\text {film }} \mathrm{cm}^{-1}: 2965,2935,1634$, 1507, 1233, 1228, 1095, 843; ${ }^{1} \mathrm{H}$ and ${ }^{13} \mathrm{C} \mathrm{NMR} ;{ }^{36} \mathrm{EI} / \mathrm{MS} \mathrm{m} / z$ (rel. int): $432[\mathrm{M}]^{+}$(12), 205 (100), 2221 (85), 236 (90), 208 (30); HRESIMS $[\mathrm{M}+\mathrm{H}]^{+}$calcd for $\mathrm{C}_{24} \mathrm{H}_{33} \mathrm{O}_{7} 433.2221$ found 433.2234 . Data for compound 3a: pale yellow oil; $[\alpha]_{\mathrm{D}}^{21}-71.4($ c $1 \times$ $\left.10^{-4} \mathrm{~mol} \mathrm{~L}^{-1}, \mathrm{CH}_{2} \mathrm{Cl}_{2}\right)$; ${ }^{1} \mathrm{H}$ and ${ }^{13} \mathrm{C} \mathrm{NMR}^{15}$

\section{Conflicts of interest}

There are no conflicts to declare.

\section{Acknowledgements}

This work was funded by grants provided by FAPESP (09/51850-9, 14/50316-7), CNPq, and PRP-USP (Pró-Reitoria de Pesquisas da USP). MJK and HVL are grateful to CNPq for research fellowships, and CSR acknowledges FAPESP for a scholarship. The authors are indebted to the Laboratório de Computação Cientifica Avançada (LCCA), Universidade de São Paulo (SP, Brazil) for computer facilities.

\section{References}

1 R. S. Ward, Nat. Prod. Rep., 1999, 16, 75-96.

2 J. Y. Pan, S. L. Chen, M. H. Yang, J. Wu, J. Sinkkonen and K. Zou, Nat. Prod. Rep., 2009, 26, 1251-1292.

3 P. K. Agrawal and R. S. Thakur, Magn. Reson. Chem., 1985, 23, 389-418.

4 D. A. Whiting, Nat. Prod. Rep., 1985, 2, 191-211.

5 L. B. Davin, M. Jourdes, A. M. Patten, K. W. Kim, D. G. Vassão and N. G. Lewis, Nat. Prod. Rep., 2008, 25, 1015-1090.

6 T. Biftu and R. Stevenson, Phytother. Res., 1987, 1, 97-106.

7 D. Holloway and F. Scheinmann, Phytochemistry, 1974, 13, 1233-1236.

8 J. M. Barbosa, M. S. da Silva, M. Yoshida and O. R. Gottlieb, Phytochemistry, 1989, 28, 2209-2211.

9 J. M. Saad, E. Soepadamo, X. P. Fang, J. L. McLaughlin and P. E. Fanwick, J. Nat. Prod., 1991, 54, 1681-1683.

10 H. J. Zhang, P. A. Tamez, V. D. Hoang, G. T. Tan, N. Van Hung, L. T. Xuan, L. M. Huong, N. M. Cuong, D. T. Thao, D. D. Soejarto, H. H. S. Fong and J. M. Pezzuto, J. Nat. Prod., 2001, 64, 772-777.

11 C. S. Ramos, S. A. Vanin and M. J. Kato, Phytochemistry, 2008, 69, 2157-2161.

12 N. P. Lopes, M. J. Kato and M. Yoshida, Phytochemistry, 1999, 51, 29-33.

13 M. Kuroyanagi, K. Yoshida, A. Yamamoto and M. Miwa, Chem. Pharm. Bull., 2000, 48, 832-837. 
14 H. K. Fun, K. Sivakumar, B. C. Yip, A. H. Othman and I. M. Said, Acta Crystallogr., Sect. C: Cryst. Struct. Commun., 1996, 52, 414-416.

15 H. Greger, T. Pacher, S. Vajrodaya, M. Bacher and O. Hofer, J. Nat. Prod., 2000, 63, 616-620.

16 Y. Qin, C. L. Yin and Z. H. Cheng, Molecules, 2013, 18, 1363613644.

17 T. Biftu, J. C. Chabala, J. Acton, T. Beattie, D. Brooker, R. Bugianesi, M. N. Chang, P. C. Chiang, N. Gamble, N. Girotra, D. Graham, C. H. Kuo, M. Ponpipom, S. Sahoo, T. Y. Shen, K. L. Thompson, S. S. Yang, S. B. Hwang and T. Doebber, Prostaglandins, 1988, 35, 846.

18 R. C. C. Martins, L. R. Latorre, P. Sartorelli and M. J. Kato, Phytochemistry, 2000, 55, 843-846.

19 L. D. Ferreira, D. R. Callejon, A. Engemann, B. Cramer, H. U. Humpf, V. P. de Barros, M. D. Assis, D. B. da Silva, S. de Albuquerque, L. T. Okano, M. J. Kato and N. P. Lopes, Planta Med., 2012, 78, 1939-1941.

20 L. G. Felippe, D. C. Baldoqui, M. J. Kato, V. D. Bolzani, E. F. Guimarães, R. M. B. Cicarelli and M. Furlan, Phytochemistry, 2008, 69, 445-450.

21 T. J. Schmidt, Phytochem. Lett., 2012, 5, 632.

22 M. M. O. Cabral, J. A. Alencar, A. E. Guimarães and M. J. Kato, J. Am. Mosq. Control Assoc., 2009, 25, 103-105.

23 A. Leite, M. J. Kato, R. O. A. Soares, A. E. Guimarães, J. R. Santos-Mallet and M. M. O. Cabral, Rev. Bras. Farmacogn., 2012, 22, 517-521.

24 J. J. Chen, E. T. Chou, C. Y. Duh, S. Z. Yang and I. S. Chen, Planta Med., 2006, 72, 351-357.

25 H.-W. Liu, X.-Z. Yu, D. Padula, G. Pescitelli, Z.-W. Lin, F. Wang, K. Ding, M. Lei and J.-M. Gao, Eur. J. Med. Chem., 2013, 59, 265-273.

26 J. L. Wu, N. Li, T. Hasegawa, J. Sakai, S. Kakuta, W. X. Tang, S. Oka, M. Kiuchi, H. Ogura, T. Kataoka, A. Tomida, T. Tsuruo and M. Ando, J. Nat. Prod., 2005, 68, 1656-1660.

27 M.-M. Bai, W. Shi, J.-M. Tian, M. Lei, Y. H. Kim, J. H. Kim, Y. N. Sun and J.-M. Gao, J. Agric. Food Chem., 2015, 63, 2198-2205.

28 H. S. Kim, C. M. Wooten, Y. Park and J. Y. Hong, Org. Lett., 2007, 9, 3965-3968.

29 K. Nihei, K. Konno, L. S. C. Bernardes, N. P. Lopes, S. Albuquerque, I. de Carvalho, M. T. Pupo, R. C. C. Martins and M. J. Kato, ARKIVOC, 2004, 112-126.
30 L. S. C. Bernardes, M. J. Kato, S. Albuquerque and I. Carvalho, Bioorg. Med. Chem., 2006, 14, 7075-7082.

31 H. Nishiwaki, K. Nakayama, Y. Shuto and S. Yamauchi, J. Agric. Food Chem., 2014, 62, 651-659.

32 A. M. Rimando, J. M. Pezzuto, N. R. Farnsworth, T. Santisuk, V. Reutrakul and K. Kawanishi, J. Nat. Prod., 1994, 57, 896904.

33 T. J. Schmidt and J. Heilmann, Planta Med., 2000, 66, 749751.

34 J. G. Blears and R. D. Haworth, J. Chem. Soc., 1958, 19851987.

35 R. C. C. Martins, J. H. G. Lago, S. Albuquerque and M. J. Kato, Phytochemistry, 2003, 64, 667-670.

36 S. F. Fonseca, L. E. S. Barata, E. A. Ruveda and P. M. Baker, Can. J. Chem., 1979, 57, 441-443.

37 M. J. Frisch, G. W. Trucks, H. B. Schlegel, G. E. Scuseria, M. A. Robb, J. R. Cheeseman, J. A. Montgomery Jr, T. Vreven, K. N. Kudin, J. C. Burant, J. M. Millam, S. S. Iyengar, J. Tomasi, V. Barone, B. Mennucci, M. Cossi, G. Scalmani, N. Rega, G. A. Petersson, H. Nakatsuji, M. Hada, M. Ehara, K. Toyota, R. Fukuda, J. Hasegawa, M. Ishida, T. Nakajima, Y. Honda, O. Kitao, H. Nakai, M. Klene, X. Li, J. E. Knox, H. P. Hratchian, J. B. Cross, C. Adamo, J. Jaramillo, R. Gomperts, R. E. Stratmann, O. Yazyev, A. J. Austin, R. Cammi, C. Pomelli, J. W. Ochterski, P. Y. Ayala, K. Morokuma, G. A. Voth, P. Salvador, J. J. Dannenberg, V. G. Zakrzewski, S. Dapprich, A. D. Daniels, M. C. Strain, O. Farkas, D. K. Malick, A. D. Rabuck, K. Raghavachari, J. B. Foresman, J. V. Ortiz, Q. Cui, A. G. Baboul, S. Clifford, J. Cioslowski, B. B. Stefanov, G. Liu, A. Liashenko, P. Piskorz, I. Komaromi, R. L. Martin, D. J. Fox, T. Keith, M. A. Al-Laham, C. Y. Peng, A. Nanayakkara, M. Challacombe, P. M. W. Gill, B. Johnson, W. Chen, M. W. Wong, C. Gonzalez and J. A. Pople, Gaussian, 03Revision B.05, Gaussian Inc., Pittsburgh, 2003.

38 H. Matsuura, H. Yoshida, M. Hieda, S. Yamanaka, T. Harada, K. Shin-ya and K. Ohno, J. Am. Chem. Soc., 2003, 125, 1391013911.

39 P. Gilli, V. Bertolasi, L. Pretto, L. Antonov and G. Gilli, J. Am. Chem. Soc., 2005, 127, 4943-4953.

40 S. Hanessian, G. J. Reddy and N. Chahal, Org. Lett., 2006, 8, 5477-5480. 